1830-1831 pp. До заслуг попечителя відносяться постійно зростаюча кількість учнів і студентів, відкриття нових гімназій, училищ та шкіл, проведення реформ з реорганізації училищ округу. Сучасники підкреслювати виняткову роль попечителя в успішному функціонуванні Київського навчального округу. Це підтверджується порівнянням із діяльністю наступників Брадке на посаді попечителя князя С. Давидова та генерала О. Траскіна. У роки попечительства Брадке Київський навчальний округ утвердився як адміністративна одиниця, в Університеті Св. Володимира зосередилися кращі викладачі Крем'янецького ліцею та молоді кадри, запрошені 3 інших вузів. Протягом 18321838 рр. в окрузі були створені передумови для стабільного функціонування навчальних закладів, закладено фундамент для подальшого розвитку вищої освіти.

\title{
Література
}

1. Сірополко С. Історія освіти в Україні. К, 2001; Рождественский С. Очерки по истории систем народного просвещения в России в ХУІП-ХІХ веках. Т. 1. - СПб., 1912; Мединский Е. Н. История русской педагогики с древнейших времеи до великой пролетарской революции. - М, 1936, Демков М.И. История русской педагогики. - Часть III. - Новая русская педагогия (XIX век).- М, 1909. 2. Шмидт Е. История средних учебных заведений в России / Е. Шмидт. - СПб., 1878; К истории народного образования на Украине в 1-ой четверти ХІХв.// Киевская старина. - 1898. - №5; Доманицкий В. К К истории частных пансионов в Киевской губ. в начале ХІХв. // Киевская. старина. -1901. - № 6. 3. Высшие и центральные государственные учреждения России. 1801-1917 гг. - Т. 1 - Высшие государственные учреждения. СПб.: Наука, 1998. 4. Рождествеиский С. В. Исторический обзор деятельности Министерства Народного Просвещения 1802-1902 / С. В. Рождественский. - СПб., 1902. 5. Сборник постановлений по Министерству Народного Просвещения. - 7.2. Царствование Императора Николая I. Отделение I. 1825-1839. - СПб., 1864. 6. Детальніше біографію С.Ф. фон Брадке див.: Столетие Киевской первой гимназии (1809-1811-1911 гг.) - Т. 1-11. - К, 1911; Воспоминания К. С. Веселовского /Русская старина. -1903. - Т. 116. - №10; Русский биографический словарь. [Т. 3]: БетанкурБякстер. - СПб., 1908; Брадке Е. Ф. Автобиографические записки // Русский архив. 1875. - № 1, 3; Новый энциклопедический словарь под общей редакцией академика К. К. Арсеньева. -Т. 7. - СПб., 1912. 7. Брадке Е. Ф. Автобиографические записки / Е. Ф. Брадке // Русский архив. -1875. - №1. 8. Столетие Киевской первой гимназии (1809-1811-1911 гг.). - Т. 1-11. - К, 1911. 9. Воспомииания К. С. Веселовского// Русская старина. - 1903.-Т. 116. - № 10. 10. Журнал министерства народного просвещения. - 1834. - Кн. 2. - № 4, апрель.

УДК. 37.011.3-051(092)

Михайло Лашко

\section{ПРОБЛЕМА НАРОДНОГО ВЧИТЕЛЯ У ТВОРЧІЙ СПАДЩИНІ М. ГРІНЧЕНКО}

Лашко М. В. Проблема народного вчителя у творчій спадщині М. Грінченко

У статті на основі аналізу маловідомих творів української просвітниці й педагога М. Грінченко (1863-1928) охарактеризовано іiї ідеї щодо народного вчителя, розглянуто вимоги до його особистості та виокремлено низку питань, які хвилювали діячку.

Ключові слова: народний учитель, школа, учні, творча спадщина, Марыя Грінченко.

Лашко М. В. Проблема народного учителя в творческом наследии М. Гринченко. 
В статье на основе анализа малоизвестных произведений М. Гринченко охарактеризованы ее идеи о народном учителе, рассмотрены требования к его личности и выделен ряд интересовавших деятельницу вопросов.

Ключевые слова: народный учитель, школа, ученики, творческое наследие, Мария Гринченко.

Lashko M. V. The popular teacher problem in M. Grinchenko's intellectual heritage

The article characterizes M. Grinchenko's little known works and her ideas about popular teacher, distinguishes some questions which interested her, and analyses her demands to teachers personal characteristics.

Key words: popular teacher, school, pupils, intellectual heritage, Maria Grinchenko.

Зміни, що відбулися в житті сучасного українського суспільства, позитивно вплинули на реформування освітнього простору. Відповідно до визначеної в Державній національній програмі «Освіта» («Україна XXI століття» (1993) [4] стратегії розвитку освітньої галузі пріоритетним завданням стала розбудова національної системи освіти як найважливішої ланки виховання свідомих громадян України. Це знайшло відображення і в Законі України «Про освіту» (1996) [7], і в Національній доктрині розвитку освіти (2001) [8]. Орієнтація на національний вектор освіти, ії органічне поєднання 3 історією і традиціями, на збереження та збагачення культури актуалізує розроблення історико-педагогічної тематики, що дає змогу обгрунтувати взаємодію традиційного й унікального в педагогіці, установити зв'язок ідей минулого та сучасних інноваційних освітніх пошуків. Для успішного розв'язання цього завдання потрібно ввести в науковий обіг достовірні факти історії української освіти й осмислити розвиток вітчизняної педагогічної думки.

Нині завдяки низці суспільно-політичних змін, що відбулися в Україні за останні двадцять років, у науковців 3'явилася можливість повернути з небуття заборонені в радянські часи імена багатьох педагогів та громадських діячів. 3 огляду на це важливим $\epsilon$ вивчення творчої спадщини відомої просвітниці, педагога, мовознавця, письменниці М. Грінченко (Загірньої). Ії ім'я на тривалий час було викреслене з радянської науки за відстоювання ідей щодо створення національної школи. Цим і пояснюється незначна кількість досліджень науково-педагогічної спадщини діячки. Сьогодні іiі ім'я знову повертається до наукового простору.

Історіографічний аналіз свідчить, що творчий доробок М. Грінченко висвітлено досить фрагментарно. Поодинокі факти, що стосуються іiі біографії та наукової спадщини, розпорошені по різних публікаціях, а тому не систематизовані. Це, зокрема, праці Л. Березівської, Н. Копиленко, О. Лугового, М. Наумової, О. Неживого та Л. Неживої тощо. Деякі аспекти літературної творчості просвітниці розкрито в монографії Л. Неживої «Марія Загірня: Літературний портрет» (2003) [9]. Редакційновидавничу діяльність висвітлено в дисертації М. Думанської «Організаційно-видавничі та редакторські аспекти діяльності Марії Грінченко» (2010) [5]. Зрозуміло, що й проблема народного вчителя не стала предметом окремого дослідження, що зумовило потребу більш глибокого аналізу та спеціального методологічного підходу.

Meта статmі- визначити й охарактеризувати ідеї М. Грінченко щодо ролі й діяльності народного вчителя.

Передусім зазначимо, що в суспільному житті Російській імперії кінця XIX початку XX ст. народний учитель був політично й соціально незахищеним (переслідування, постійна матеріальна скрута, безправність у всіх сферах життя). Водночас, як зазначає Л. Березівська, проблема вчителя наприкінці XIX - на початку 
XX ст. була надзвичайно актуальною, бо реалізація та втілення в педагогічну практику передових дидактичних принципів і методів навчання значною мірою залежать від особи учителя [1].

М. Грінченко, працюючи тривалий час учителькою початкових класів (Харківщина, Катеринославщина), особисто відчула всі злигодні шкільного життя. Тому зовсім не випадково, що доля вчителя не була їй байдужою та знайшла відгук у їі творчій спадщині.

Свої ідеї щодо народного вчителя просвітниця розкрила в неопублікованих статтях «Колись і тепер» (1922) [2], «Про заборону викладання української мови в школі» (б.д.) [3], листах до В. Дурдуківського, оригінали яких зберігаються у фондах Інституту рукопису Національної бібліотеки імені Вернадського і на сьогоднішній день майже не досліджені науковцями, а також в опублікованих «Спогадах» (1999) [6].

Особливу увагу у своїй спадщині М.Грінченко приділяла ролі вчителя в суспільстві, адже з усіма недоліками навчально-виховного процесу в народній школі їй довелося зіткнутися у процесі своєї педагогічної діяльності. Так, у неопублікованій статті «Колись і тепер» вона охарактеризувала рівень фахової підготовки вчителів, навела один 3 епізодів свого вчительського життя. У школі, у якій їй довелося працювати, «був учитель - молодий хлопець, що тільки 2-й рік як скінчив учительську семінарію. Та він у школі не вчив, він тільки показав нам, як учити... а сам поїхав у повіт» [2, арк. 3]. Це свідчить, що вчителі не мали спеціальної педагогічної підготовки для роботи в навчальних закладах і не володіли теорією та методикою навчання. Тому вони здійснювали навчальний процес на власний розсуд, їхню діяльність ніхто не контролював і не допомагав як молодим спеціалістам методичними рекомендаціями. У цій же статті М. Грінченко визначила й характерні риси тогочасних шкільних учителів, котрі всіма засобами намагалися зрівнятися 3 можновладцями, зрікаючись свого простолюдного походження, тим самим відсторонюючись і від народу, для якого мали б працювати, нести для нього освіту. «Вони, - наголошувала діячка, - гордували народом і силкувалися бути серед народу «паничами», носили навіть кашкети з кокардами. Вони були малоосвічені і доброго в них було тільки й того, що мали педагогічні ухватки, яких ми несемінаристи не мали» [2, арк. 4]. Цим М. Грінченко показала, що відчуження від народу призводило до загального духовного виродження, чого й домагався царський режим, для якого не потрібні були освічені і свідомі особистості.

На той час учителями найчастіше ставали випускники семінарій, де навчалися ті, хто закінчив двокласну школу, тобто сільські діти. Як описує діячка, семінаристи всіляко прагнули і мовою, і одягом якнайбільше відрізнятися від селян, тобто відмовлялися від національних коренів. Звідси можна зробити висновок, що в майбутніх випускників повністю нівелювалися світогляд, переконання, засвоєні в родині моральні якості. Учителі, які цуралися свого народу, не могли дати учням нічого корисного, вони тільки калічили розум і душу дітей, убивали в них прагнення до знань. Але й у цих непростих умовах було немало справжніх учителів, які жили життям народу. I їх не лякали ні переслідування, ні всілякі заборони. Просвітниця окреслила ці проблеми у статті «Про заборону викладання української мови в школі», яка збереглася в рукописному вигляді [3]: «Всім тяжко було жити, а надто вчителям... Тяжко було в ті часи вчителювати в усіх школах од найвищої до найнижчої, але сугубо тяжко було вчителювати в народних школах. Не можна було вживати української мови навіть для пояснення, і скільки було таких випадків, що у вчителя віднімано було право вчителювання, за те що пояснив щось учням рідною мовою.... Учитель не мав права мати в себе вдома вкраїнські книжки, передплачувати українські газети 3 Галичини...» [3, арк. 2]. Отже, в умовах агресивної русифікації українців царський 
режим не тільки забороняв українську мову в школі, а й повністю позбавляв учителя можливості вживати ії в навчально-виховному процесі. Крім того, ще й використовував мовне питання як причину для втручання в особисте життя вчителів.

Політика влади, спрямована на деградацію шкільництва загалом, призводила до морального звиродніння вчителя народної школи. Через свою загальну обмеженість, малокультурність сільські вчителі, як стверджує просвітниця, не доростали до усвідомлення свого становища. Навіть не намагаючись щось змінити, щоб бути для учнів зразком та джерелом морально-етичних норм поведінки, вони здебільшого ставали об'єктом для глузувань, а інколи й причиною ненависті 3 боку школярів. Звичайно, педагоги 3 низьким рівнем моралі не могли організувати навчально-виховний процес на належному рівні та бути взірцем.

Проблема морального обличчя вчителя настільки турбувала М. Грінченко, що вона раз у раз намагалася оголити іiі, розмірковуючи над причинами і наслідками такого деградування у своїх статтях і нотатках, адже сама часто була свідком подібних безчинств. Не оминула вона цю проблему і в мемуарах. Застосування фізичних покарань для учнів було в учительській практиці звичайною справою. У стосунках між учителями й учнями не могло бути й натяку на взаємоповагу, тож учитель не міг бути ні прикладом для наслідування, ні авторитетом у знаннях.

Із наведених М. Грінченко із скрупульозністю справжнього літописця вчительського життя прикладів можна зробити висновок про панування в народних школах авторитарної системи навчання, коли дозволялися щодо беззахисних учнів і жорстоке поводження, i застосування фізичних покарань. Украй сумнівні педагогічні методи нікого не дивували, а тому широко застосовувалися і вважалися найбільш прийнятними. Чи варто тоді говорити про низький рівень викладання, коли залякуваннями й погрозами втовкмачувалися знання. Отже, самі умови тогочасного вчителювання в народній школі, безконтрольність і безкарність спричинювали побудову навчального процесу не на принципах гуманізму та взаємоповаги вчителя й учнів, а на жорстокості та насиллі.

Аморальними були і стосунки між самими учителями. На проблемі цих стосунків М. Грінченко наголошувала у «Спогадах»: «Особливо це стосувалося двокласної школи, де, як правило, було два вчителі: завідуючий школою і просто вчитель. I платню, і права вони мали однакові, але завідуючий був господарем у школі. Здається, пишатися не було чим, але завідуючий завсігди силкувався показати другому вчителеві свою зверхність...» [6, с. 34].

Водночас діячка зазначала, що в однокласних школах учитель 3 помічниками й помічницями співіснували здебільшого мирно і конфлікти між ними були не загальним явищем, а скоріше прикрим винятком. Вона пояснювала це тим, «що по однокласних школах учителювали не великовчені психологи-семінаристи з учительської семінарії, а звичайні собі люди» 6 , с. 34]. Отже, М. Грінченко уявляла вчителя стриманою, толерантною особою, яка 3 повагою ставиться до колег. Вона чудово розуміла, що тільки сприятлива і творча атмосфера в самому учительському колективі здатна забезпечити належний рівень навчання дітей.

Особливу увагу М. Грінченко приділяла і проблемі взаємин учителя та учнів. Різні ситуації вона змалювала так: «...знаннів мали вони небагато, були недисципліновані. Себто вчителів вони боялися і при їх поводилися тихо, а тільки зостались без учителя, то зараз у класі починалось бешкетування. I таке поводження було зовсім зрозуміле, коли пригадати, що вчителі в їх мінялися дуже і любили гостювати в урядника і т. ін. і приходили в клас люті 3 похмілля» [6, с. 33]. Ці факти вкотре свідчать про безвідповідальність народних учителів, низький рівень їхньої культури, що негативно позначалося на поведінці учнів. 
Викликали занепокоєння в М. Грінченко не лише стан викладання, а й умови життя і праці вчителів народних шкіл, про що мали турбуватися ті, від кого це найбільше залежало. Вона писала: «Будуючи школи... наче спеціально, дбали про те, щоб для вчительської хати дати місця якнайменше, нікому, мабуть, і на думку не спадало, що вчитель може мати сім’ю і що навіть для його вчительської праці погано буде, якщо він не матиме собі хати окремої від сім'ї...» [6, с. 34]. Звідси можна зробити висновок, що вчитель народної школи був незахищений соціально і позбавлений належної уваги суспільства. Упосліджений і зневажений навіть на побутовому рівні, він не був особою, чий авторитет міг формувати суспільну думку, впливати на життя народу, його загальнокультурний рівень.

М. Грінченко, розмірковуючи про роль учителя в народному середовищі, не обминала і загальнотеоретичних питань. Так, вона критично висловлювалася про реформи, які впроваджували земства у систему народної освіти: «...У ті часи земства... заходилися заводити школи. Де не було зовсім школи, там заводили нову, а де була якась сільська школа, то починала зватися земською» [6, с. 28].

Складними були стосунки вчителя і з волосним начальством. М. Грінченко наводить непоодинокі випадки, коли це начальство зневажливо ставилося до вчителя [6, с. 29, 31]. Безправність народного вчителя і безкарність начальства нерідко визначали й освітню систему загалом, правила гри якої змушене було приймати все тогочасне суспільство.

М. Грінченко гостро критикувала й діяльність «стипендіатів» у сільській школі. Так тоді називали випускників, які закінчили цю ж таки школу й мали ще зиму ходити до неї та допомагати вчителеві, привчаючись таким чином до вчителювання, а вже потім їхали земськими стипендіатами до вчительської семінарії. Але, як зазначала діячка, «зі стипендіатів не було ніякої помочі, бо доручити їм учити школярів не можна було, а коли вони зоставалися в класі пильнувати порядку, то школярі їх не слухали» [6, c. 38]. Такі «педагогічні інновації» були безперспективними, бо що міг дати учням стипендіат, який не мав елементарних педагогічних знань. М. Грінченко довелося на практиці зіткнутися з результатами їхньої діяльності, і вона оцінювала ці знання так: «Учні третьої групи, які мали здавати екзамен, відрізнялися від учнів другої групи тільки тим, що, як читали, то не в кожному слові робили помилки... і багато було таких, що своє ім'я і прізвище писали 3 помилками» [6, с. 48]. Це свідчить про те, що такі педагогічні експерименти з боку вчителів тільки порушували навчальний процес, позбавляючи учнів можливості навчитися за надзвичайно короткий час хоча б елементарної грамоти.

Отже, на основі аналізу згаданих джерел можна викоремити низку проблем, які хвилювали М. Грінченко на початку ХХ ст. Це рівень фахової підготовки вчителя, його моральні якості, стосунки між учителями, поводження педагога з учнями, умови життя і праці вчителя народної школи, відносини народного вчителя 3 волосним начальством, діяльність стипендіатів у сільській школі. Велику увагу просвітниця приділяла особистості педагога, який, володіючи не лише високою загальною культурою, а й спеціальними педагогічними знаннями i навичками, покликаний забезпечувати належний рівень навчально-виховного процесу в школі. Вона бачила вчителя народної школи високоморальною, високоосвіченою, національно свідомою людиною, яка сумлінно виконує свій обов'язок. Ці ідеї не втратили актуальності й нині в умовах розбудови особистісно зорієнтованої освіти в Україні.

У своїй творчій спадщині М. Грінченко не обмежувалася проблемою народного вчителя. У іiї статтях і мемуарах порушувались і питання народної школи, що потребує подальших досліджень. 


\section{Література}

1. Березівська Л. Освітньо-виховна діяльність київських просвітницьких товариств (друга половина XIX - поч. XX ст.) / Л. Березівська. - К. : Молодь. - 1999. 192 с. 2. Грінченко М. Колись і тепер / М. Грінченко // IP НБУ ім. В. Вернадського НАН України, ф. I, спр.32547, 14 арк. 3. Грінченко М. Про заборону викладання української мови в школі / М. Грінченко // ІР НБУВ, ф. I, спр.32571, 14 арк. 4. Державна національна програма «Освіта» («Україна ХХІ століття») // Освіта. - 1993. - № 44 - 46. С. 1-13. 5. Думанська М. Організаційно-видавничі та редакторські аспекти діяльності Марії Грінченко : автореф. дис... канд. наук із соц. комунікацій / М. Думанська. Запоріжжя, 2010. - 18 с. 6. Загірня М. Спогади / М. Загірня; упоряд., передм., прим. Л. Л. Неживої - Луганськ: Шлях, 1999. - 160 с. 7. Закон України про внесення змін і доповнень до закону Української РСР «Про освіту». - К. : ГЕНЕЗА, 1996. - 36 с. 8. Національна доктрина розвитку освіти України у XXI столітті. - К. : Шкіл. світ, 2001. - 23 с. 9. Нежива Л. Марія Загірня : літер. портрет / Л. Нежива. - Луганськ : Знання, 2003. $-170 \mathrm{c}$.

УДК 37(477)

Ольга Рудь

\section{ФОРМУВАННЯ ОСОБИСТОСТІ МАЙБУТНІХ ПЕДАГОГІВ У ХРЕСТОВОЗДВИЖЕНСЬКОМУ ТРУДОВОМУ БРАТСТВІ МИКОЛИ НЕПЛЮЄВА}

Рудь О. М. Формування особистості майбутніх педагогів у Хрестовоздвиженському Трудовому Братстві Миколи Неплюєва.

У статті проаналізовано систему навчання і виховання Миколи Неплюєва, виявлено особливості формування особистості майбутнього педагога у Хрестовоздвиженському Трудовому Братстві.

Ключові слова: Хрестовоздвиженське Трудове Братство, формування особистості педагога-майстра, естетичне виховання, релігійне виховання, моральне виховання, розумовий розвиток.

Рудь О. Н. Формирование личности будущих педагогов в Крестовоздвиженском Трудовом Братстве Николая Неплюева.

В статье проанализирована система обучения и воспитания Николая Неплюева, обнаружены особенности формирования личности будущего педагога в Крестовоздвиженском Трудовом Братстве.

Ключевые слова: Крестовоздвиженское Трудовое Братство, формирование личности педагога-мастера, эстетичное воспитание, религиозное воспитание, моральное воспитание, умственное развитие.

Rud O.N. The future teacher personality forming in Krestovozdvizhensk Labour Fraternity of Nickolay Neplyuev.

The article deals with the educational system of Nickolay Neplyuev The features of future teacher personality forming in Krestovozdvizhensk Labour Fraternity are found out.

Key words: Krestovozdvizhensk Labour Fraternity, future teacher personality forming, aesthetic education, religious education, moral education, mental development.

На сучасному етапі розвитку суспільства постає питання про підготовку висококваліфікованого вчителя, здатного в умовах масової освіти забезпечувати 